Portland State University

PDXScholar

6-14-2019

\title{
Stratigraphic Evidence of Cascadia Earthquake Induced Relative Sea Level Change at Netarts Bay, Oregon
}

Jazzy M. Graham-Davis

Portland State University

Follow this and additional works at: https://pdxscholar.library.pdx.edu/honorstheses

Let us know how access to this document benefits you.

\section{Recommended Citation}

Graham-Davis, Jazzy M., "Stratigraphic Evidence of Cascadia Earthquake Induced Relative Sea Level Change at Netarts Bay, Oregon" (2019). University Honors Theses. Paper 757.

https://doi.org/10.15760/honors.774

This Thesis is brought to you for free and open access. It has been accepted for inclusion in University Honors Theses by an authorized administrator of PDXScholar. Please contact us if we can make this document more accessible: pdxscholar@pdx.edu. 


\title{
Stratigraphic Evidence of Cascadia Earthquake Induced Relative Sea Level Change at Netarts Bay, Oregon
}

\author{
by \\ Jazzy M Graham-Davis
}

A thesis submitted in partial fulfillment of the requirements for

University Honors

Bachelor of Science

in

Geology

Thesis Advisor:

Ashley R. Streig

Portland State University

2019 


\begin{abstract}
I present new dendrochronologic age constraints from a buried tree slab collected below the marsh surface at Netarts Bay, Oregon. A ghost forest is apparent at low tide on the central-eastern margin of Netarts Bay. 120 meters inland from the bay front, incision into marsh exposures reveal buried trees protruding 1.43 meters below the marsh surface and extending from the $4^{\text {th }}$ layer of buried marsh soils overlain by tsunami sands. I interpret this stratigraphic sequence as evidence for tectonic subsidence and abrupt paleotsunami inundation. Prior research at the southern marsh at Netarts Bay has correlated Cascadia Subduction Zone (CSZ) ruptures to the stratigraphic record with sediment cores that have a pattern of marsh soils overlain by a sharp contact to sand, transitioning to mud and then marsh soils again, bulk sample radiocarbon dating, and diatom analysis. Sediment cores collected at the ghost forest site show the same stratigraphic pattern indicative of CSZ related subsidence. I correlated ghost forest trees exposed along the bay with trees protruding from incised marsh stratigraphy with both differential GPS and lidar elevation measurements for several ghost forest trees. I collected a cross section slab from a buried ghost forest tree, sanded the slab, counted growth rings at a consistent decadal interval, and submitted select samples for $\mathrm{C} 14$ accelerator mass spectrometry age dating. The species of the tree is an Oregon Ash (Fraxinus latifolia) which has no salinity tolerance and can grow close to sea level. I have wiggle matched $\mathrm{C} 14$ ages and the known interval between tree ring samples to the $\mathrm{C} 14$ calibration curve using OxCal 4.3, to find that the tree died 286-392 $\mathrm{CE}$ at a $95.4 \%$ confidence interval, and 290-313 CE at a 68.2\% confidence interval. I compared the dendrochronologically constrained death of the trees with other on-shore and off-shore paleoseismic studies that constrained the timing of prehistoric CSZ ruptures, indicating that this was the $5^{\text {th }}$ prehistoric earthquake back from present.
\end{abstract}




\section{Introduction}

Globally, prehistoric records of subduction zone earthquakes are determined by evaluating stratigraphic evidence of uplift and subsidence along the margin in the over-riding plate within a subduction zone. The subducting plate is locked by friction against the over-riding plate in the interseismic period between earthquakes. Accumulated strain is released in a coseismic earthquake when friction is overcome and slip occurs releasing the strain, resulting in a subduction zone earthquake (Yeats, 2004). In the interseismic period, strain accumulates causing the over-riding crust to bend to accommodate the strain over the length of the interseismic period (Yeats, 2004). Along the trench, the edge of the over-riding plate gets pulled downward along the plate interface, while on-shore the crust experiences uplift. A point in between these two regions of deformation acts as a hinge as they deform up and down simultaneously (Darienzo \& Peterson, 1990; Yeats,

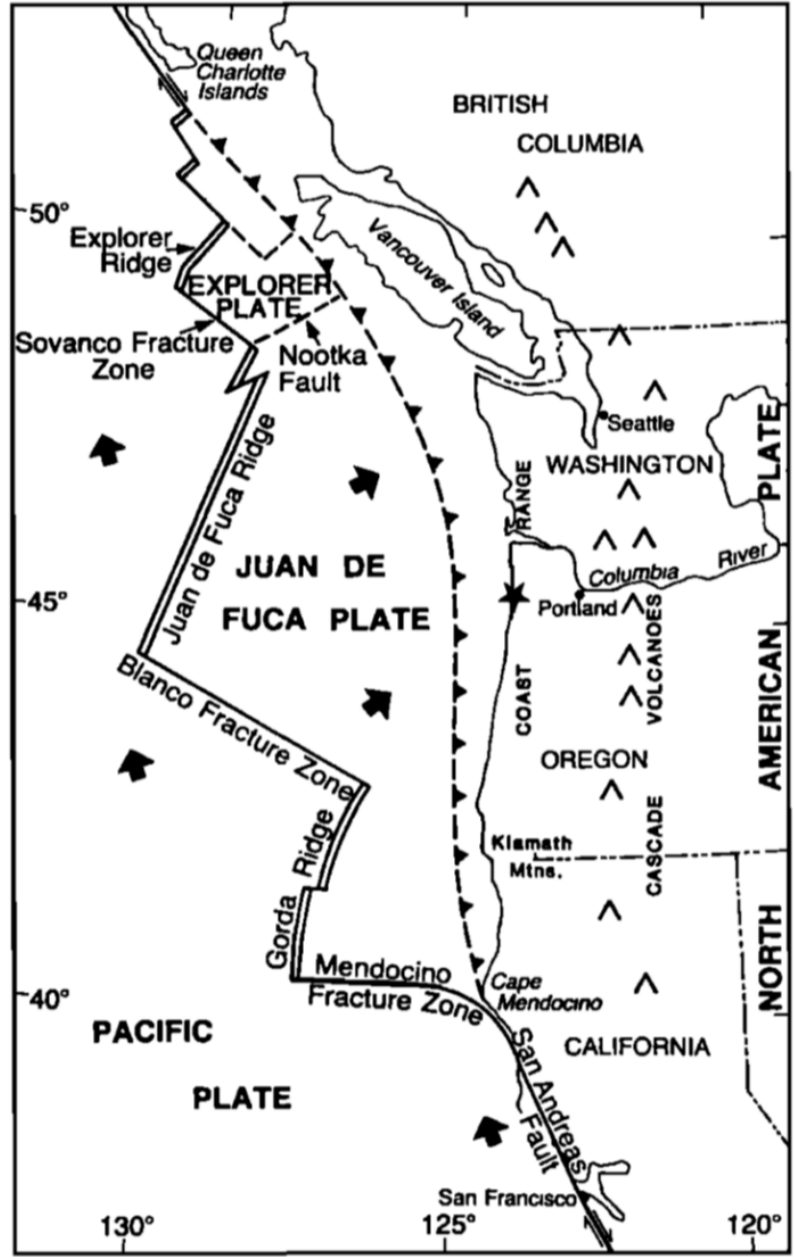

Figure 1: Map of Cascadia Subduction Zone with a star at Netarts Bay (Darienzo \& Peterson, 1990).
2004). In a coseismic earthquake on-shore subsidence occurs instantaneously, an example of elastic rebound, as the strain is released and interseismic uplifted regions subside and the crust resumes its pre-strain shape. The toe of the over-riding plate is uplifted during the earthquake as subsidence occurs on the other side of the hinge point (Yeats, 2004). Stratigraphic evidence of these types of earthquakes ranges from uplifted corals in Indonesia along the Sumatra subduction zone (Meltzner et al., 2012), to ghost forests in the Pacific Northwest along the Cascadia Subduction Zone (Atwater et al., 1991). Due to the vertical crustal movement associated with subduction zone earthquakes, tsunamis are caused by the displacement of water from the over-riding plate's toe uplifting along the margin during the rupture. 
The Cascadia Subduction Zone (CSZ) lies off-shore of the Pacific Northwest from Northern California to British Columbia, Canada (Figure 1), and is shown as a thrust fault with triangles on the over-riding plate in Figure 1. Coastal regions along the CSZ experience interseismic uplift and instantaneous coseismic subsidence and have well established stratigraphic earthquake and tsunami records for 19 to 20 full length subduction zone earthquakes (Goldfinger et al., 2012; Goldfinger et al., 2016). The purpose of this project is to evaluate sequences of intertidal marsh and tsunami stratigraphy and an apparent ghost forest identified at Netarts Bay (Figure 2) to understand relative seal level drop associated with the $5^{\text {th }}$ earthquake back in the Cascadia paleoseismic records. Prior research in Netarts Bay was conducted along a marsh at the

south end of the bay (Peterson \& Darienzo, 1988; Darienzo, 1991). Sediment cores along the shoreline reveal a repeating several hundred-year cycle of relative sea level change. The cores have a pattern of peat overlain by a sharp contact to sand, transitioning to mud and then peat again, which has been interpreted as evidence for tectonic subsidence and abrupt paleotsunami inundation (Peterson \& Darienzo, 1988; Darienzo \& Peterson, 1990; Darienzo, 1991; Darienzo \& Peterson, 1995). On the central-eastern margin of the bay a ghost forest is apparent during low tides, elevation data for these trees and stratigraphic correlations from exposed stratigraphy reveal that these deceased trees extend from a layer of marsh soils overlain by tsunami sands. The death of these trees corresponds with coastal subsidence dropping a mature forest into the intertidal zone. This project uses carbon-14 (C14) wiggle matching from tree growth ring samples to find a precise age for timing of when the trees died. I have compared the dendrochronologically constrained death of the trees with the timing of the paleoseismic history of CSZ ruptures to identify it as the $5^{\text {th }}$ prehistoric earthquake.

\section{Background}

Offshore along the Pacific Northwest the Juan de Fuca (JdF) oceanic plate dives beneath the North American plate forming the Cascadia Subduction Zone. In the cold upper crust, the subducting JdF plate is locked by friction with the over-riding North American plate and the strain accumulates in the crust and causes uplift along the Pacific Northwest coast up to about 50 kilometers inland (Witter, 2011). When enough strain has accumulated and friction at the contact between the plates is overcome, the fault slips and the strain is released as a coseismic event occurs, and the regions that experienced uplift in the interseismic period subsides up to $2 \mathrm{~m}$ in Oregon, and up to $1 \mathrm{~m}$ for Netarts Bay (Darienzo \& Peterson, 1990; Witter et al., 2011). The CSZ last 


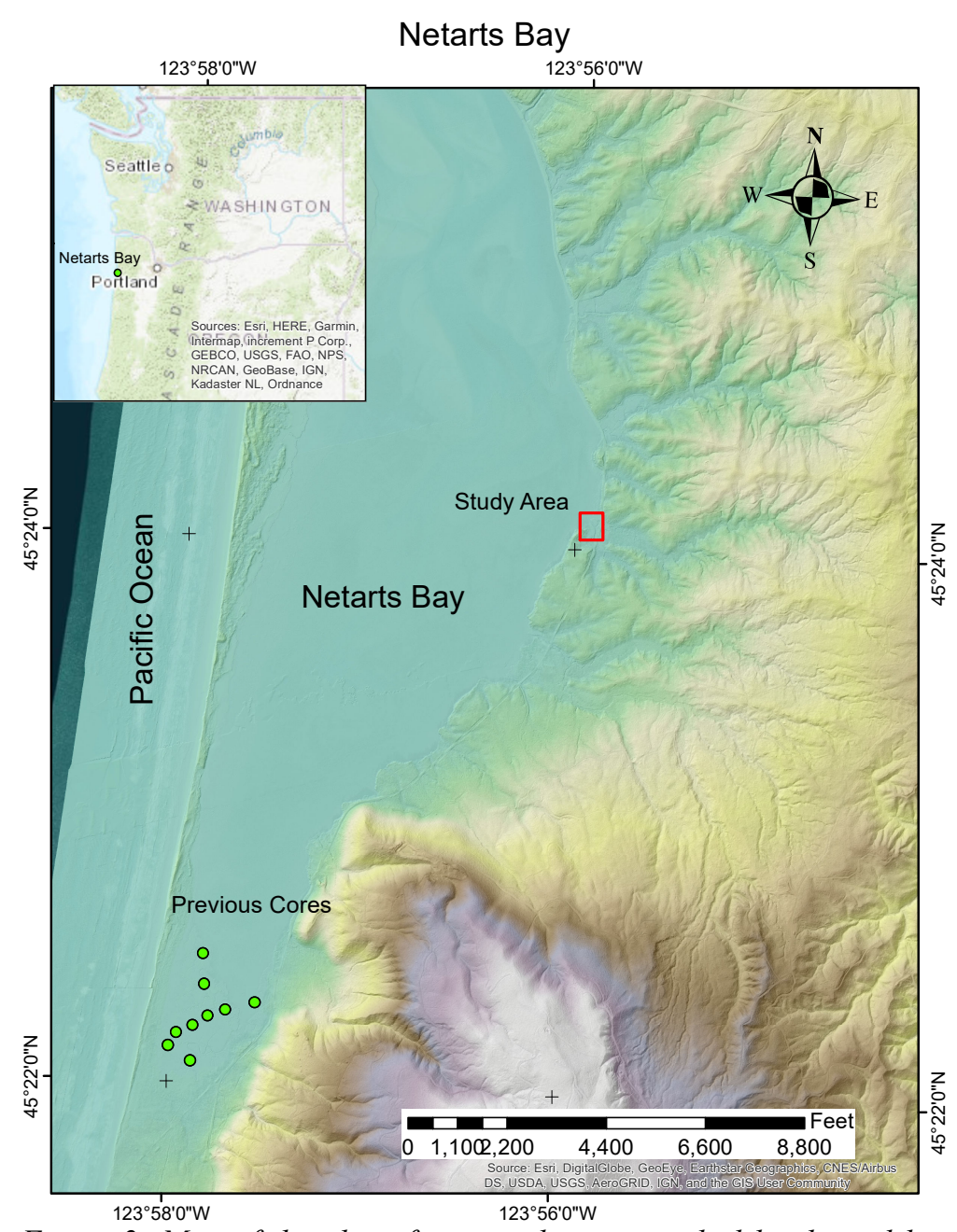

Figure 2: Map of the ghost forest study area marked by the red box. Sediment cores in the south bay shown by green points collected by Darienzo and Peterson, 1990, and Darienzo, 1991. These cores revealed tsunami sands coupled with down dropped marsh stratigraphy for 3 earthquakes within 3 meters of the marsh surface (Darienzo and Peterson, 1990; Darienzo, 1991; Peterson et al., 1993). ruptured 319 years ago and has an average recurrence interval of 430 years for the northern segment, and 340 years in central Oregon (Goldfinger et al., 2016).

During each rupture, elastic rebound causes the uplifted coastline to subside submerging anything along the shore (Darienzo \& Peterson, 1990; Peterson et al., 1993; Yeats, 2004). Grassy wetlands in Netarts Bay and other locations along the coast have been subjected to the uplift and subsidence cycle, which is recorded in the stratigraphy when wetlands are buried by tsunami sand and succeeded by intertidal mud (Peterson \& Darienzo, 1988; Peterson et al., 1993). The wetlands die once buried

becoming the peat layers seen in sediment cores that contain roots and small sticks (Peterson \& Darienzo, 1988; Darienzo \& Peterson, 1990). This organic material can be radiocarbon dated to provide the maximum age of the burial event caused by the earthquake.

Organics from the uppermost buried peat layer identified in sediment cores taken at the south end of Netarts Bay yielded C14 ages of 290-520 calendar years before present (cal. BP) (Peterson \& Darienzo, 1988; Peterson et al., 1993). The C14 ages overlap in time and correspond with the last full-length rupture of the CSZ 319 years ago (Peterson \& Darienzo, 1988; Peterson et al., 1993; Goldfinger et al., 2016). The $4^{\text {th }}$ peat layer down the stratigraphic core was dated to 1354-1769 cal. BP and the $5^{\text {th }}$ peat layer to $1540-1869$ cal. BP (Darienzo, 1991), representing 
maximum burial ages of the wetland. An in-situ Spruce stump in the $5^{\text {th }}$ buried marsh top at the northeastern shore of the bay was dated with a single sample by Darienzo (1991) to $1820 \pm 60$ radiocarbon years B.P. (RCYBP). These authors converted C14 ages to calendar ages for individual samples using the CALIB calibration program, which does not take into account the relative age between samples known from the stratigraphic record (Peterson and Darienzo, 1988; Ramsey et al., 2001). Peterson and Darienzo (1988) first identified exposed in situ tree stumps on the tidal flat at Wee Willie's Restaurant (in 1988), now Nevør Shellfish Farm (Figure 3). Peterson and Darienzo (1988) do not provide any detailed stratigraphic correlations at the site and have no age results for the tree stumps. A small creek cuts through the wetland creating cutbanks of exposed stratigraphy. The stumps are also protruding from peat layers exposed in cutbanks

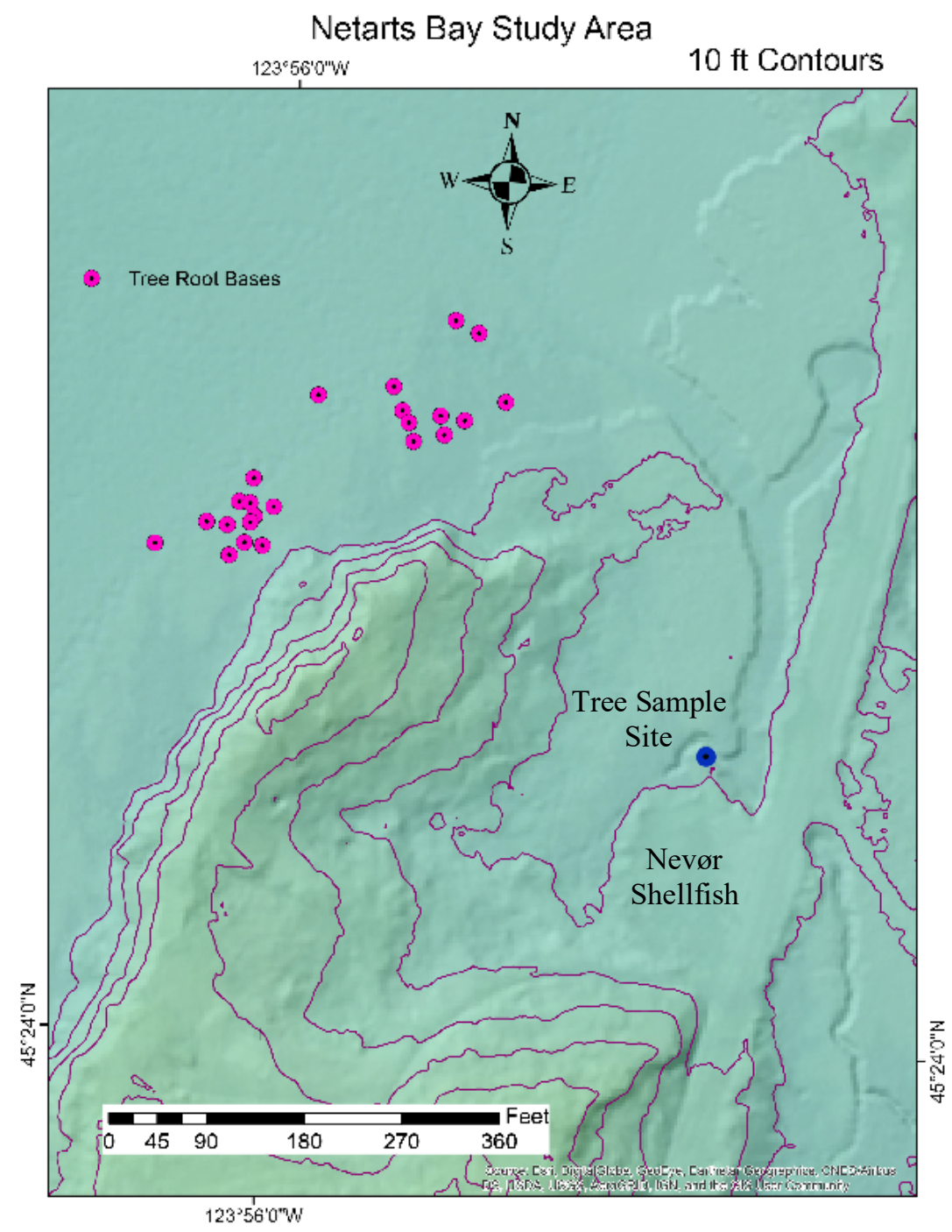

Figure 3: Study area map showing extensive area of in-situ root bases in pink points marked from aerial imagery, the tree slab sample site with a blue point, and the location of the Nevør Shellfish Farm store and parking.
(Peterson et al., 1993). Sampling multiple growth rings from the buried tree can be used to precisely assign calendar years to radiocarbon ages, revealing when the tree died. The tree death correlates to the subsidence associated with a coseismic event, constraining the earthquake age.

Carbon concentrations in the atmosphere have changed over time, these changes are recorded in annual tree growth rings (Reimer et al., 2013). In order to yield precise calendar ages for the death of the tree, growth rings must be counted, samples of tree growth rings 
must be collected, and the time interval between rings must be known with high confidence $(+/-1$ year). Annual growth rings are interpreted by distinctions between the earlywood and latewood growth that together represent one year (Speer, 2013). The amount of C14 in each growth ring sample is measured with $\mathrm{C} 14$ accelerator mass spectrometry (AMS), and the amount of measured C14 compared to stable carbon isotopes of C12 and C13 yields the radiocarbon age. Since atmospheric carbon has changed over time, having the known time interval between samples will create a unique pattern of radiocarbon years versus calendar years to match to the calibration curve in a process known as wiggle matching (Kojo et al., 1994).

\section{Hypotheses}

1. Tree stumps along the shoreline at the eastern margin of Netarts Bay are a ghost forest. The death of these trees coincides with the timing of a CSZ earthquake and record relative sea level resulting from subsidence in that event. I can find the minimum elevation of this tree species above sea level in modern day forests and can estimate the minimum amount of subsidence associated with the pre-historic CSZ earthquake that dropped the forest into the intertidal zone.

Or

2. The death of the trees in the ghost forest does not correspond in time with a CSZ earthquake and instead records eustatic sea level change in Netarts Bay, and along the northern Oregon coast.

\section{Methods}

This study comprised of field collection of marsh sediment stratigraphy at the site and a tree slab from the ghost forest. In the lab I dried and polished the tree slab and collected growth ring samples for $\mathrm{C} 14$ analysis. I also reanalyzed previous $\mathrm{C} 14$ analysis for the southern marsh at Netarts Bay (Figure 2). Details are explained in the sections below. 

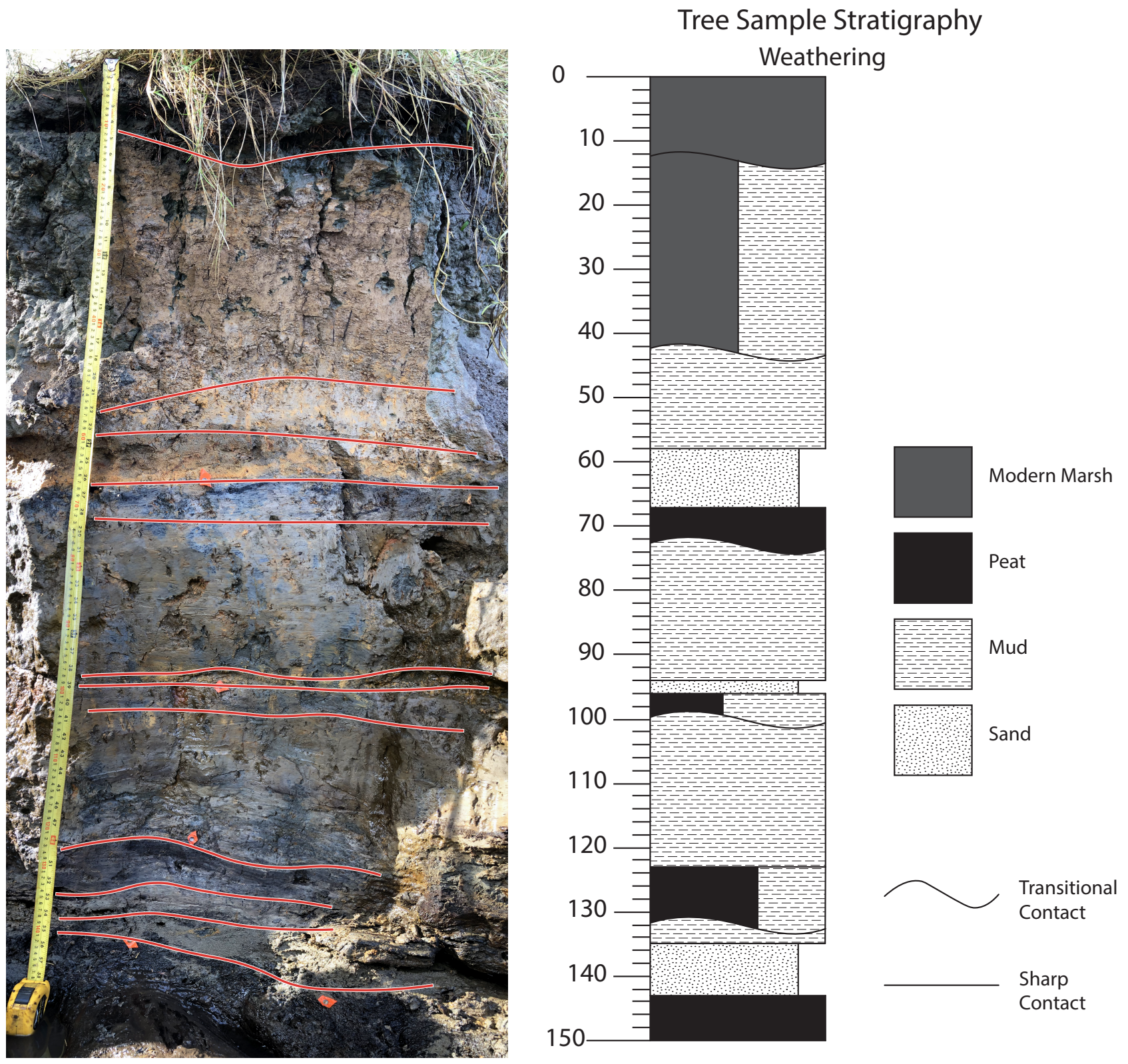

Figure 4: Stratigraphic column of the exposed stratigraphy directly adjacent to the tree sample site. Left image is the exposure with unit contacts marked, right image is the interpreted column. Note that the buried tree roots are associated with the lowest peat in this stratigraphic column.

\section{Sediment Stratigraphy}

I have compared stratigraphy exposed by the cutbank at the tree sample site (Figure 4) to sediment cores taken in the same area and at the southern marsh (Figure 2) (Peterson \& Darienzo, 1988). The ghost forest is stratigraphically associated with the $4^{\text {th }}$ earthquake horizon down marked by an abrupt transition from peat to tsunami sand (Figure 4). 


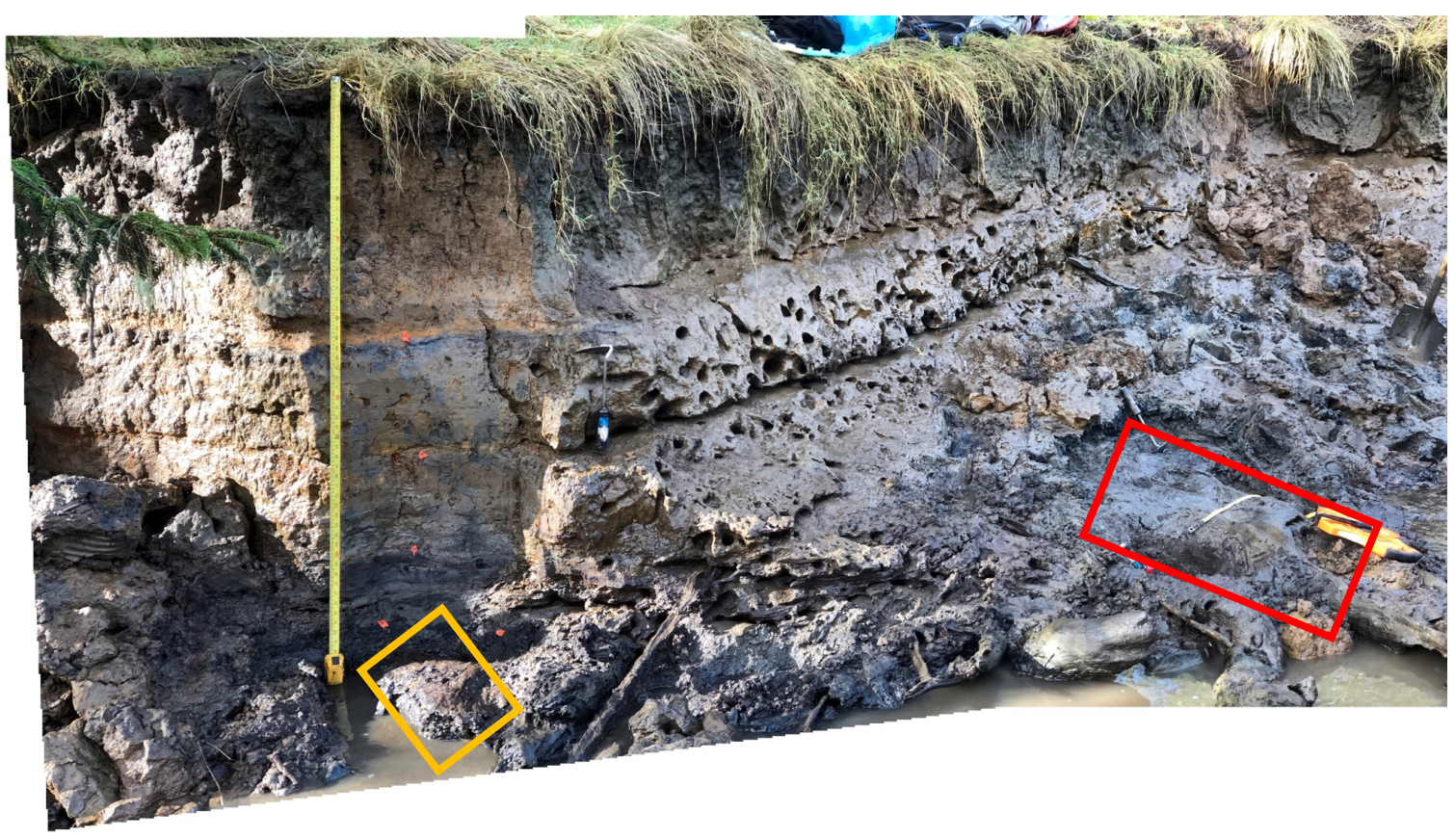

Figure 6: The tree sample site with the sample marked by the red box. The exposed stratigraphy contains additional trees in the lowest unit marked by the orange box that correlates to the sample.

Figure 5: Tree sample slab with longest transect shown by pink line. Dashed line indicates tracing a ring around the tree to a wider section of growth. Red markers indicate where samples for radiocarbon dating were taken

\section{Sample Collection}

I have collected one slice of a buried tree stump from the ghost forest with preserved tree rings. This was done by manually excavating it out enough to remove with a chainsaw. I took note of the stratigraphy directly adjacent to the tree sample to mark the bed it was removed from (Figure 6). I have found the elevation using lidar of the tree sample removed, and other




exposed in situ root bases on the tidal mud flat to correlate them to the same stratigraphic layer. I have also gotten approximate locations of in situ root bases from satellite imagery as well as the elevation of the current tree line (Figure 3).

\section{Tree Ring Sampling}

I dried out the tree stump cross-section and sanded it down to a polished surface with several grits of sandpaper from coarse to very fine. The slab was polished until the cellular structure within growth rings was apparent with hand lens magnification which allowed me to count several transects of the growth rings to find the longest, most complete growth record (Figure

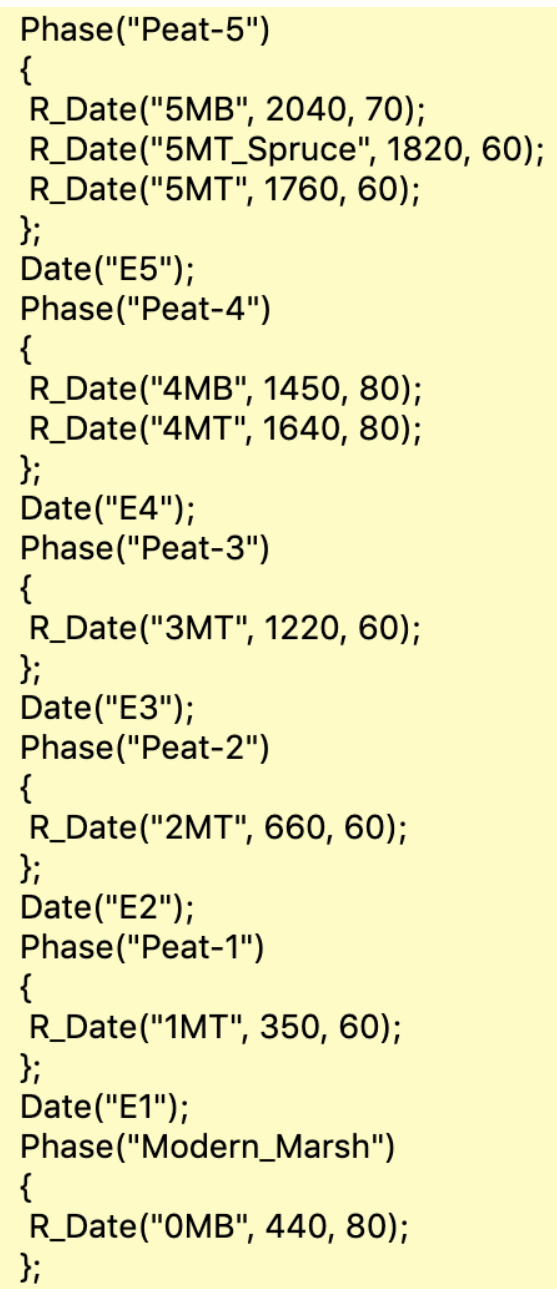

Figure 7: A portion of the code to recalibrate radiocarbon ages to calendar ages in OxCal. Each sample is marked as marsh top (MT) or marsh bottom (MB). "E\#" dates each earthquake event to subside the marsh surface.
6). I was checking for any ring abnormalities such as rings pinching out or false rings that do not represent a full year of growth that could interfere with getting a known time interval between samples (Speer, 2013). I took samples at a known time interval (Table 4 and Table 5), to be radiocarbon dated and used for wiggle matching with the radiocarbon calibration curve (Kojo, 1994).

\section{Statistical Modeling of Previous Radiocarbon Ages}

I modeled radiocarbon ages from Darienzo, 1991 and Peterson et al., 1993 (Table 1) to calibrate earthquakes identified at the southern Netarts Bay core sites (Figure 2) to calendar years. I used OxCal software version 4.3 (Ramsey \& Weninger, 2001). OxCal software uses a Bayesian statistical modeling approach, which takes into account the relative age between the previous marsh surfaces that the samples were taken from (Ramsey et al., 2001). This is shown in Figure 7 as each phase represents a single relative age. The earthquake date is a resulting probability density function of the time between each stratigraphic phase. 


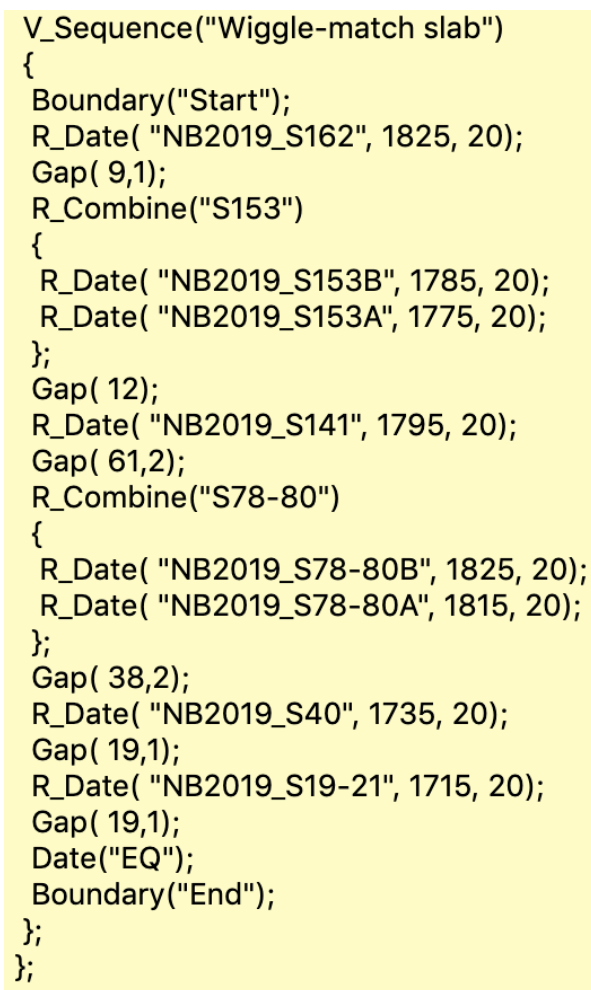

Figure 8: Code to wiggle match radiocarbon ages to calendar ages using the known time interval gap and any error in counting that gap. The earthquake that subsided the ghost forest is dated as "EQ".

\section{Radiocarbon Dating and Analysis}

I sent six tree ring wood samples to the Lawrence Livermore National Laboratories Center for Accelerator Mass Spectrometry (LLNL-CAMS) for C14 dating (Table 3). The ratio of $\mathrm{C} 14$ still present in the sample to stable carbon isotopes yields the age in radiocarbon years before present. I used the radiocarbon years BP and my time interval between samples to wiggle-match to the calibration curve (Figure 10) with OxCal 4.3 statistical age modeling software (Ramsey et al., 2001; Ramsey, 2019). I ran two versions of the calibration, a D sequence that takes into account the known time interval between samples, and a V sequence which also adds an error to this time interval (Figure 8). This process yields the precise age of the tree samples in cal. BP and Common Era (CE), which is a maximum age for the burial event, i.e. the earthquake and tsunami.

Table 1: Radiocarbon Ages from Darienzo (1991) and Peterson et al. (1993) that were modeled in OxCal in this study. Samples were bulk peat taken from the marsh top (MT) and marsh bottom (MB), one exception is the wood sample from an in-situ Spruce in $5 M T$

Table 1

\begin{tabular}{l|c|c|c|c|c|c}
\hline Beta \# & Buried Marsh \# & 14C age & \pm & ${ }^{13}$ C Adj & \pm & Cal BP \\
\hline \hline 24932 & OMB & 450 & 80 & 440 & 80 & $310-626$ \\
24933 & 1MT & 370 & 60 & 350 & 60 & $290-520$ \\
41638 & 2MT & 660 & 60 & & & $540-690$ \\
24934 & $3 \mathrm{MT}$ & 1270 & 60 & 1220 & 60 & $970-1290$ \\
24520 & $4 \mathrm{MT}$ & 1670 & 80 & 1640 & 80 & $1354-1769$ \\
24521 & $5 \mathrm{MT}$ & 1840 & 60 & 1760 & 60 & $1540-1869$ \\
24936 & $5 \mathrm{MT} \mathrm{Spruce}$ & 1820 & 60 & & & \\
41668 & 5MB & 2090 & 70 & 2040 & 70 & $1870-2298$ \\
24522 & 6MT & 2600 & 70 & & & $2489-2849$ \\
& $7 \mathrm{MT}$ & 3220 & 90 & 3170 & 90 & $3145-3636$ \\
\hline
\end{tabular}




\section{Results}

\section{Aerial Imagery and Lidar Analysis}

The in-situ root bases on the tidal flat (Figure 3) and in the cutbanks show a consistent elevation of $5 \mathrm{ft}$. The current tree line elevation is about $10 \mathrm{ft}$. The tree slab sample is an Oregon Ash (Fraxinus latifolia), which has no salinity tolerance and can grow close to sea level (Neimeic et al., 1995).

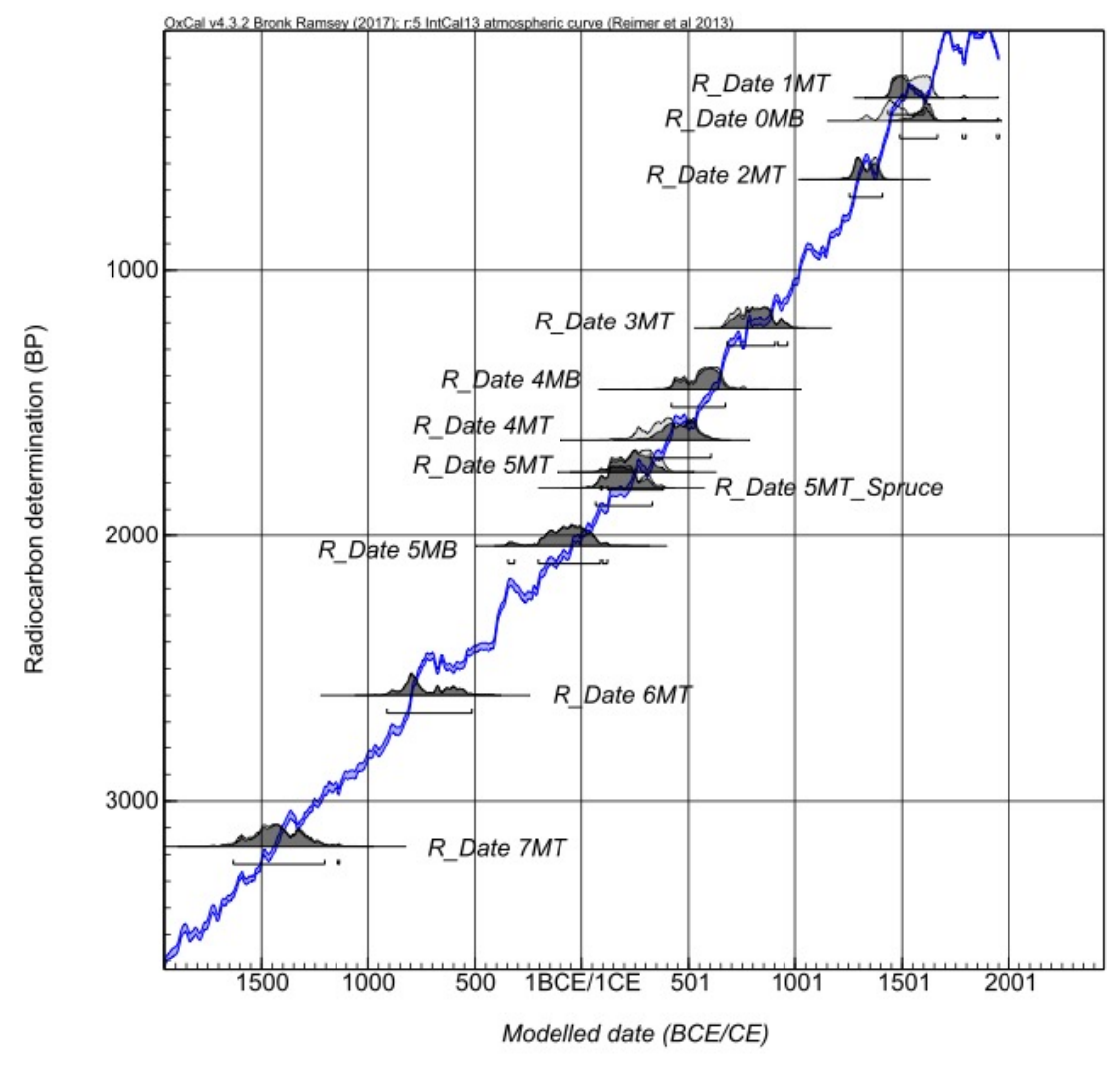

Radiocarbon dated marsh samples are shown with "R_Date"

Figure 9: Modeled ages from Darienzo, 1991 and Peterson et al., 1993 shown on the carbon calibration curve.

and the correlating marsh surface.

Modeled earthquake ages are labeled as "E\#" indicating the number of earthquakes from present. The agreement indices are shown and are well above the threshold for the sample data to be considered in agreement with the model. The age results are given in Before Common Era (BCE) as a negative number, and Common Era (CE) as a positive number. The results are also shown with probability density functions (PDFs) plotted on the carbon calibration curve (Figure 9). 
Table 2: Results of the modeled ages from Darienzo, 1991 and Peterson et al., 1993.

Table 2

\begin{tabular}{|c|c|c|c|c|c|c|c|c|c|c|}
\hline \multirow{3}{*}{$\begin{array}{l}\text { Confidence } \\
\text { Interval (\%) } \\
\text { Name } \\
\end{array}$} & \multicolumn{4}{|c|}{ Unmodelled (BCE(-)/CE) } & \multicolumn{4}{|c|}{ Modelled (BCE(-)/CE) } & \multicolumn{2}{|c|}{ Agreement Indices } \\
\hline & \multicolumn{2}{|c|}{68.2} & \multicolumn{2}{|c|}{95.4} & \multicolumn{2}{|c|}{68.2} & \multicolumn{2}{|c|}{95.4} & \multirow{2}{*}{$\begin{array}{c}\text { Amodel } \\
89.7 \\
\mathrm{~A}\end{array}$} & \multirow{2}{*}{$\begin{array}{c}\text { Aoveral } \\
90.2\end{array}$} \\
\hline & from & to & from & to & from & to & from & to & & \\
\hline R_Date 0MB & 1409 & 1622 & 1318 & 1644 & 1573 & 1644 & 1490 & 1953 & 69.5 & 98.1 \\
\hline \multicolumn{11}{|c|}{$\begin{array}{l}\text { Phase } \\
\text { Modern Marsh }\end{array}$} \\
\hline E1 & & & & & 1505 & 1609 & 1444 & 1659 & & 99.5 \\
\hline R_Date 1MT & 1470 & 1632 & 1444 & 1649 & 1447 & 1535 & 1435 & 1603 & 99.4 & 99.4 \\
\hline \multicolumn{11}{|l|}{ Phase Peat-1 } \\
\hline E2 & & & & & 1353 & 1485 & 1289 & 1541 & & 99.5 \\
\hline R_Date 2MT & 1279 & 1391 & 1261 & 1411 & 1275 & 1387 & 1255 & 1409 & 99.5 & 99 \\
\hline \multicolumn{11}{|l|}{ Phase Peat-2 } \\
\hline E3 & & & & & 931 & 1271 & 797 & 1350 & & 99.1 \\
\hline R_Date 3MT & 711 & 885 & 669 & 961 & 724 & 890 & 680 & 966 & 100.2 & 99.1 \\
\hline \multicolumn{11}{|l|}{ Phase Peat-3 } \\
\hline E4 & & & & & 599 & 785 & 505 & 879 & & 99.5 \\
\hline R_Date 4MT & 335 & 536 & 232 & 596 & 387 & 542 & 321 & 605 & 104.6 & 99.1 \\
\hline R_Date 4MB & 475 & 664 & 415 & 763 & 437 & 653 & 421 & 672 & 98.4 & 99 \\
\hline \multicolumn{11}{|l|}{ Phase Peat-4 } \\
\hline E5 & & & & & 270 & 438 & 198 & 517 & & 99.6 \\
\hline R_Date 5MT & 215 & 380 & 128 & 402 & 139 & 321 & 90 & 383 & 97.3 & 98.5 \\
\hline $\begin{array}{l}\text { R_Date } \\
5 \bar{M} T \text { Spruce }\end{array}$ & 126 & 318 & 65 & 346 & 90 & 252 & 68 & 331 & 103.3 & 98.9 \\
\hline R_Date 5MB & -161 & 46 & -348 & 123 & -159 & 47 & -347 & 122 & 99.8 & 98 \\
\hline \multicolumn{11}{|l|}{ Phase Peat-5 } \\
\hline R_Date 6MT & -839 & -556 & -911 & -516 & -838 & -556 & -911 & -515 & 100.6 & 95.5 \\
\hline \multicolumn{11}{|l|}{ Phase Peat-6 } \\
\hline R_Date 7MT & -1597 & -1302 & -1658 & -1215 & -1526 & -1296 & -1632 & -1133 & 99.2 & 97.3 \\
\hline Phase Peat-7 & & & & & & & & & & \\
\hline
\end{tabular}

Table 3: Radiocarbon age results of the ghost forest tree wood samples. Sample name and CAMS sample number shown. Ages are in radiocarbon years before present.

Table 3

\begin{tabular}{c|c|c|c|c|c|c|c|c}
\hline CAMS \# & Sample Name & $\begin{array}{c}\boldsymbol{\delta}^{\mathbf{1 3}} \mathbf{C} \\
\mathbf{\% o}\end{array}$ & Fraction Modern & $\mathbf{\pm}$ & $\begin{array}{c}\mathbf{D}^{\mathbf{1 4}} \mathbf{C} \\
\mathbf{\% o}\end{array}$ & $\begin{array}{c}\mathbf{I}^{\mathbf{4}} \mathbf{C} \\
\text { age }\end{array}$ & $\mathbf{\pm}$ \\
\hline \hline 181696 & NB2019_S19-21 & -25.3 & 0.8076 & 0.0018 & -192.4 & 1.8 & 1715 & 20 \\
181697 & NB2019_S40 & -24.9 & 0.8060 & 0.0017 & -194.0 & 1.7 & 1735 & 20 \\
181698 & NB2019_S78-70 & -26.0 & 0.7976 & 0.0018 & -202.4 & 1.8 & 1815 & 20 \\
181703 & NB2019_S78-80 dup QA & -26.0 & 0.7970 & 0.0017 & -203.0 & 1.7 & 1825 & 20 \\
181699 & NB2019_S141 & -25.9 & 0.7997 & 0.0018 & -200.3 & 1.8 & 1795 & 20 \\
181700 & NB2019_S153 & -25.5 & 0.8015 & 0.0018 & -198.5 & 1.8 & 1775 & 20 \\
181702 & NB2019_S153 dup QA & -25.5 & 0.8006 & 0.0019 & -199.4 & 1.9 & 1785 & 20 \\
181701 & NB2019_S162 & -25.4 & 0.7968 & 0.0018 & -203.2 & 1.8 & 1825 & 20 \\
\hline
\end{tabular}


Table 4: D sequence OxCal wiggle matching model. Unmodeled and modeled ages are shown in Common Era (CE) for two confidence intervals. Earthquake age marked by $E Q$.

Table 4

\begin{tabular}{|c|c|c|c|c|c|c|c|c|c|c|}
\hline & & \multicolumn{4}{|c|}{ Unmodelled (CE) } & \multicolumn{4}{|c|}{ Modelled (CE) } & \multirow{3}{*}{$\begin{array}{c}\text { Indices } \\
\mathrm{A}\end{array}$} \\
\hline \multicolumn{2}{|c|}{ Confidence Interval (\%) } & \multicolumn{2}{|c|}{68.2} & \multicolumn{2}{|c|}{95.4} & \multicolumn{2}{|c|}{68.2} & \multicolumn{2}{|c|}{95.4} & \\
\hline Name & $\begin{array}{l}\text { Gap } \\
(\text { yrs) }\end{array}$ & from & to & from & to & from & to & from & to & \\
\hline \multirow[t]{2}{*}{ EQ } & & & & & & 291 & 312 & 288 & 391 & \\
\hline & 19 & & & & & & & & & \\
\hline \multirow[t]{2}{*}{$\begin{array}{l}\text { R_Date } \\
\text { NB2019_S19-21 }\end{array}$} & & 261 & 381 & 255 & 390 & 272 & 293 & 269 & 372 & 85.4 \\
\hline & 19 & & & & & & & & & \\
\hline \multirow[t]{2}{*}{ R_Date NB2019_S40 } & & 255 & 338 & 245 & 380 & 253 & 274 & 250 & 353 & 107.1 \\
\hline & 38 & & & & & & & & & \\
\hline \multirow[t]{2}{*}{ R_Combine S78-80 } & & 141 & 234 & 135 & 237 & 215 & 236 & 212 & 315 & 88 \\
\hline & 61 & & & & & & & & & \\
\hline \multirow[t]{2}{*}{$\begin{array}{l}\text { R_Date } \\
\text { NB2019_S141 }\end{array}$} & & 171 & 316 & 135 & 322 & 154 & 175 & 151 & 254 & 71.3 \\
\hline & 12 & & & & & & & & & \\
\hline \multirow[t]{2}{*}{ R_Combine S153 } & & 231 & 319 & 174 & 330 & 142 & 163 & 139 & 242 & 24.3 \\
\hline & 9 & & & & & & & & & \\
\hline $\begin{array}{l}\text { R_Date } \\
\text { NB2019_S162 }\end{array}$ & & 139 & 226 & 131 & 238 & 133 & 154 & 130 & 233 & 100 \\
\hline
\end{tabular}

Radiocarbon Ages and Wiggle Matching

The radiocarbon age results are shown in Table 3. The table includes the measured stable isotope ratio of carbon $\left(\delta^{13} \mathrm{C}\right)$ measured by isotope ratio mass spectrometry, the difference in the carbon ratio from present, the normalized depletion in C14, and the radiocarbon age using Libby's half-life for carbon of 5568 years.

The D sequence wiggle matching model results are presented in Table 4. Five out of six samples are in agreement with the model, as shown by the agreement indices. The V sequence wiggle matching model results are in Table 5 . D sequence and $\mathrm{V}$ sequence results are very similar even with the addition of the tree ring counting error. Earthquake age is marked as EQ Table 4 and Table 5, and overlaps with E5 on Table 2. The carbon calibration curve is plotted with the radiocarbon dated samples where the wiggles matched (Figure 10). 
Table 5: V sequence OxCal wiggle matching model. Age gap between samples is shown with an error.

Table 5

\begin{tabular}{|c|c|c|c|c|c|c|c|c|c|c|c|}
\hline \multirow{2}{*}{\multicolumn{2}{|c|}{ Confidence Interval (\%) }} & \multicolumn{4}{|c|}{ Unmodelled (CE) } & \multicolumn{4}{|c|}{ Modelled (CE) } & \multicolumn{2}{|c|}{ Indices } \\
\hline & & \multicolumn{2}{|c|}{68.2} & \multicolumn{2}{|c|}{95.4} & \multicolumn{2}{|c|}{68.2} & \multicolumn{2}{|c|}{95.4} & \multirow[b]{2}{*}{ A } & \multirow[b]{2}{*}{$\mathrm{C}$} \\
\hline Name & $\begin{array}{c}\text { Gap, Error } \\
\text { (yrs) }\end{array}$ & from & to & from & to & from & to & from & to & & \\
\hline \multirow[t]{2}{*}{$\overline{\mathrm{EQ}}$} & & & & & & 290 & 313 & 286 & 392 & & 98.7 \\
\hline & 19,1 & & & & & & & & & & \\
\hline \multirow{2}{*}{$\begin{array}{l}\text { R_Date } \\
\text { NB2019_S19-21 }\end{array}$} & & 261 & 381 & 255 & 390 & 271 & 294 & 267 & 373 & 85.5 & 98.3 \\
\hline & 19,1 & & & & & & & & & & \\
\hline \multirow[t]{2}{*}{ R_Date NB2019_S40 } & & 255 & 338 & 245 & 380 & 252 & 275 & 248 & 354 & 106.9 & 98.5 \\
\hline & 38,2 & & & & & & & & & & \\
\hline \multirow[t]{2}{*}{ R_Combine S78-80 } & & 141 & 234 & 135 & 237 & 215 & 237 & 211 & 315 & 87.2 & 98.9 \\
\hline & 61,2 & & & & & & & & & & \\
\hline \multirow[t]{2}{*}{$\begin{array}{l}\text { R_Date } \\
\text { NB2019_S141 }\end{array}$} & & 171 & 316 & 135 & 322 & 153 & 176 & 151 & 254 & 72 & 98.2 \\
\hline & 12,0 & & & & & & & & & & \\
\hline \multirow[t]{2}{*}{ R_Combine S153 } & & 231 & 319 & 174 & 330 & 142 & 164 & 139 & 243 & 24.4 & 97.9 \\
\hline & 9,1 & & & & & & & & & & \\
\hline $\begin{array}{l}\text { R_Date } \\
\text { NB2019_S162 }\end{array}$ & & 139 & 226 & 131 & 238 & 133 & 155 & 130 & 234 & 100.4 & 98.2 \\
\hline
\end{tabular}

\section{Discussion}

The in-situ root bases and exposed roots on the cutbanks are from the same stratigraphic layer which is a buried marsh surface. The marsh surface was inundated when it subsided which killed the trees that make up the ghost forest. The time it takes for the trees to drown is shorter than the temporal resolution of wiggle matching allowing the tree death to be an accurate age for the earthquake. Since the in-situ root bases on the tidal flat are much larger than an Oregon Ash they are inferred to be a different species.

The wiggle matching results for the earthquake age are centered on $300 \mathrm{CE}$ or $1700 \mathrm{cal}$ BP. These results overlap with age ranges for the $5^{\text {th }}$ previous earthquake in the CSZ paleoseismic 


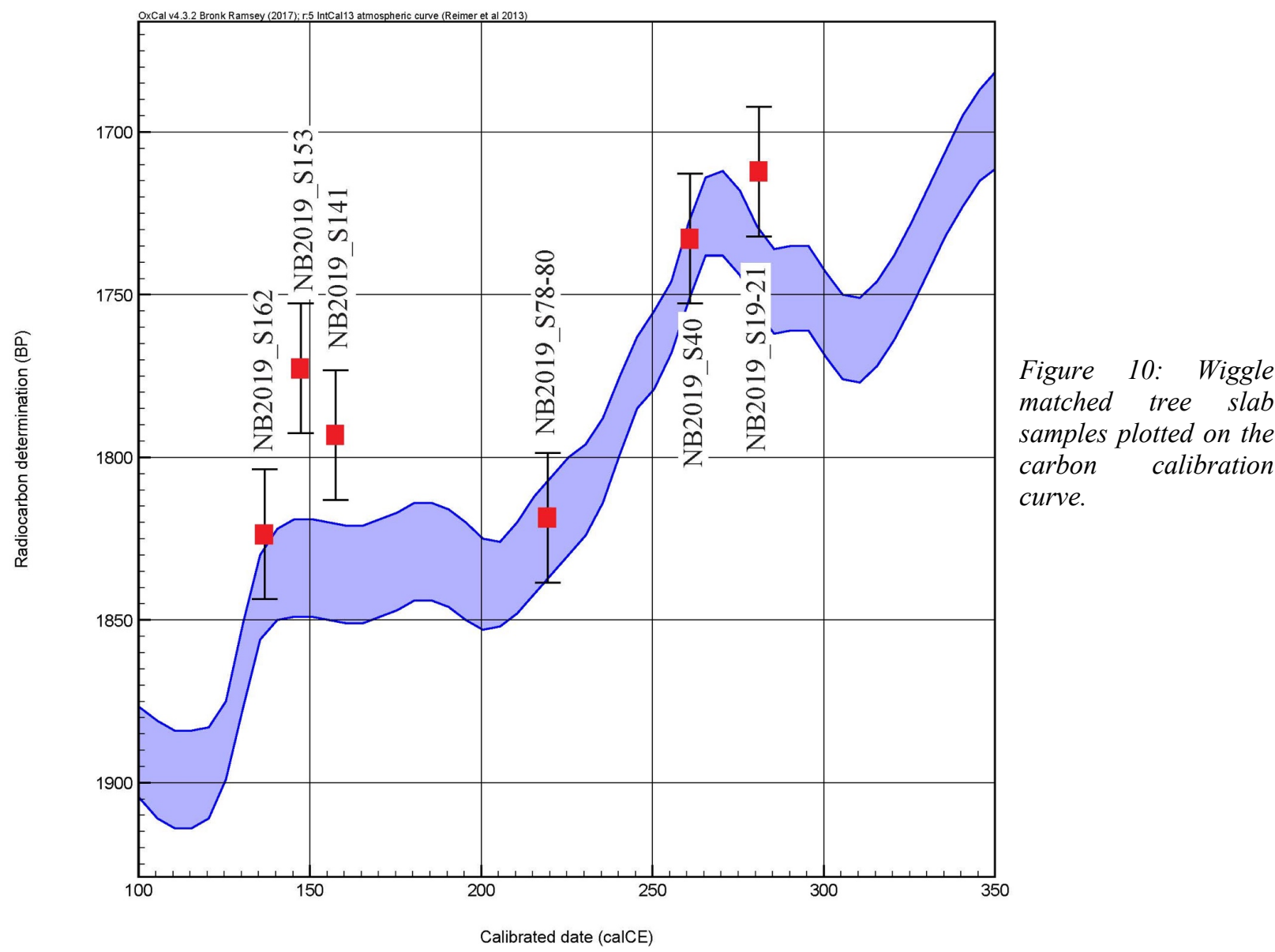

record from the modeled results of previous radiocarbon ages, other on shore stratigraphic evidence (Nelson at al., 2006), and off shore turbidite data (Goldfinger et al., 2012).

This is the $2^{\text {nd }} \mathrm{CSZ}$ earthquake age to be constrained with tree ring data, the first being the 1700 CE event (Yamaguchi et al., 1997). Figure 11 is modified from Nelson et al., 2006 and shows CSZ history correlating on shore evidence with earthquake events. The height of the box represents the age range that evidence can support. Two tree ring based evidence boxes are the shortest, representing tightly constrained ages for their respective events. Each dashed line is one earthquake event. The study site only shows 4 earthquake horizons in the stratigraphy. The missing event is inferred to be the $2^{\text {nd }}$ earthquake back. This event is often missing in the stratigraphic record as a result of the short interseismic period between the $3^{\text {rd }}$ and $2^{\text {nd }}$ events back. 


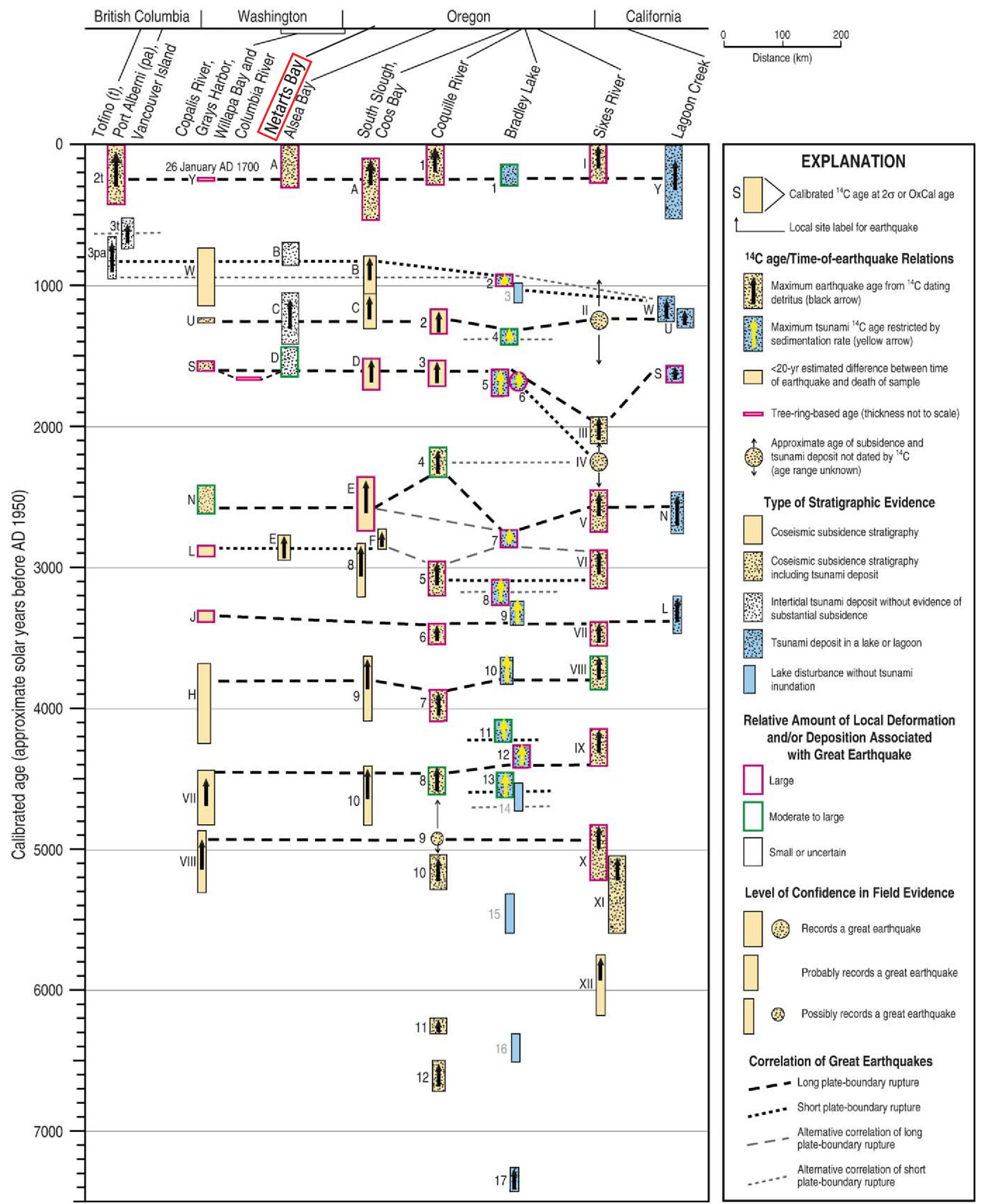

Figure 11: On shore evidence of earthquakes along the CSZ with the vertical scale of each box showing the age range that can be constrained. Two boxes are tree ring-based evidence, for the 1700 event and the $5^{\text {th }}$ event back. 


\section{Conclusion}

The $5^{\text {th }}$ prehistoric earthquake in Cascadia Subduction Zone history is constrained in this study to $286-392 \mathrm{CE}$ at a $95.4 \%$ confidence interval, and $290-313 \mathrm{CE}$ at a $68.2 \%$ confidence interval using a dendrochronologic wiggle matching technique. This is the second CSZ earthquake to be tightly constrained to within less than 100 years, and the first that predates the $1700 \mathrm{CE}$ event. Further work could measure the annual growth rings to compare to other trees and constrain the time of death, and thus earthquake, to an annual resolution.

\section{Acknowledgements}

The biggest thank you to my advisor Dr. Ashley Streig for making this all possible and going above and beyond in her duties, and Dr. Curt Peterson for passing on information about this site. Endless appreciation to Brian Chenoweth for assisting with tree sample collection. I would like to thank Dr. Daniel Ballhorn and Dr. Andrés Holz for species identification and biological insight, and Tom Guilderson at Lawrence Livermore National Lab CAMS for running radiocarbon samples. I would like to acknowledge Alison Horst, Lana Jewell, Ryan Levinson, Aleysa Orr and the PSU Department of Geology for help and support. I would not have had this opportunity without the support of my family, Brandy, and my service dog Jack. This thesis was funded by U.S. National Science Foundation grant \#1349577 awarded to Ashley Streig.

\section{References}

Atwater, B. F., Stuiver, M., \& Yamaguchi, D. K. (1991). Radiocarbon test of earthquake magnitude at the Cascadia subduction zone. Nature, 353(6340), 156-158. doi:10.1038/353156a0

Yamaguchi, D. K., Atwater, B. F., Bunker, D. E., Benson, B. E., \& Reid, M. S. (1997). Tree-ring dating the 1700 cascadia earthquake. Nature, 389(6654), 922-923. doi: 10.1038/40048

Darienzo, M. E., \& Peterson, C. D. (1990). Episodic tectonic subsidence of Late Holocene salt marshes, northern Oregon Central Cascadia Margin. Tectonics,9(1), 1-22.

doi:10.1029/tc009i001p00001 
Darienzo, M. E. (1991). Late Holocene paleoseismicity along the northern Oregon Coast (Doctoral dissertation). Retrieved from PDXScholar. Doi: 10.15760/etd.1146

Darienzo, M. E., \& Peterson, C. D. (1995). Magnitude and frequency of subduction-zone earthquakes along the northern Oregon coast in the past 3,000 years. Oregon Geology,57(1), $3-12$.

Goldfinger, C., Galer, S., Beeson, J., Hamilton, T., Black, B., Romsos, C., Patton, J., Nelson, C. H., Hausmann, R., \& Morey, A. (2016). The importance of site selection, sediment supply, and hydrodynamics: A case study of submarine paleoseismology on the northern Cascadia margin, Washington USA. Marine Geology,384, 4-46. doi:10.1016/j.margeo.2016.06.008

Goldfinger, C., Nelson, C.H., Morey, A.E., Johnson, J.R., Patton, J., Karabanov, E., GutierrezPastor, J., Eriksson, A.T., Gracia, E., Dunhill, G., Enkin, R.J., Dallimore, A., \& Vallier, T., (2012). Turbidite event history-Methods and implications for Holocene paleoseismicity of the Cascadia subduction zone. U.S. Geological Survey Professional Paper 1661-F, 170 p, 64 figures, available at http://pubs.usgs.gov/pp/pp1661/f

Kojo, Y., Kalin, R. M., \& Long, A. (1994). High-Precision "Wiggle-Matching" in Radiocarbon Dating. Journal of Archaeological Science,21(4), 475-479. doi:10.1006/jasc.1994.1047

Meltzner, A. J., Sieh, K., Chiang, H., Shen, C., Suwargadi, B. W., Natawidjaja, D. H., Philibosian, B., \& Briggs, R. W. (2012). Persistent termini of 2004- and 2005-like ruptures of the Sunda megathrust. Journal of Geophysical Research: Solid Earth, 117(B4). doi:10.1029/2011jb008888

Niemiec, S.S., Ahrens, G. R., Willits, S. \& Hibbs, D.E. (1995). Hardwoods of The Pacific Northwest. Forest Research Laboratory, Oregon State University, Corvallis. Research Contribution $8.115 \mathrm{p}$. 
Peterson, C. D., \& Darienzo, M. E. (1988). Coastal neotectonic field trip guide for Netarts Bay, Oregon. Oregon Geology,50(9/10), 99-106.

Peterson, C. D., Darienzo, M. E., Burns, S. F., \& Burris, W. K. (1993). Field trip guide to Cascadia paleoseismic evidence along the northern Oregon coast: Evidence of subduction zone seismicity in the central Cascadia margin. Oregon Geology,55(5), 99-114.

Ramsey, C. B., Plicht, J. V., \& Weninger, B. (2001). 'Wiggle Matching’ Radiocarbon Dates. Radiocarbon,43(2A), 381-389. doi:10.1017/s0033822200038248

Ramsey, C. B. (2019). OxCal Program, v.4.3: Radiocarbon Accelerator Unit, University of Oxford, Oxford, United Kingdom, https://c14.arch.ox.ac.uk/oxcal.html (last accessed 8 June, 2019).

Reimer, P. J., Bard, E., Baillie, M. G. L., Bayliss, A., Beck, J. W., Blackwell, P. G., Bronk Ramsey, C., Buck, C. E., Cheng, H., Edwards, R. L., Friedrich, M., Grootes, P. M., Guilderson, T. P., Haflidason, H., Hajdas, I., Hatté, C., Heaton, T. J., Hoffmann, D., Hogg, A. G., Hughen, K. A., Kaiser, K. F., Kromer, B., Manning, Niu, M., S. W., Reimer, R. W., Richards, D. A., Scott, E.M., Southon, J. R., Staff, R.A., Turney, C. S. M., \& J. van der Plicht (2013). IntCal13 and Marine13 radiocarbon age calibration curves, 0-50,000 years cal BP: Radiocarbon, 55, 1869-1887.

Speer, J. H. (2013). Fundamentals of tree-ring research. Tucson, AZ: The University of Arizona Press.

Witter, R. C., Zhang, Y., Wang, K., Priest, G. R., C. G., Stimely, L. L., English, J. T., \& Ferro, P. A. (2011). Simulating tsunami inundation at Bandon, Coos County, Oregon, using hypothetical Cascadia and Alaska earthquake scenarios (Oregon Department of Geology and Mineral Industries). Portland, Or.: Oregon Dept. of Geology and Mineral Industries. 
Yeats, R. S. (2004). Living with earthquakes in the Pacific Northwest. Corvallis: Oregon State University Press. 